Journal of

International Logistics and Trade

\title{
Editorial
}

\section{One Belt One Road initiative and its implications for the global economy}

The $21^{\text {st }}$ century Silk Road, the One Belt One Road (OBOR) was announced in 2013, by Chinese President Xi Jinping. The OBOR follows from the Silk Road which revolutionized the global economy and brought about cultural and technological exchanges in the $13^{\text {rd }}$ century. With many similarities to its predecessor, the New Silk Road Project can be simplified as an expansion of the efficient trade and logistics network across Eurasia. From this perspective, the New Silk Road can be interpreted as building an efficient network system among spatially distributed countries.

The OBOR is composed of five routes, three of which are land routes from China to Western Europe through Central Asia, the Middle East, and Russia, and two maritime routes through the South China Sea and the Indian Ocean respectively. The primary purpose of the OBOR is to reinforce the connectivity from China to Europe, both through the development of transportation infrastructure as well as developing economic linkages through building free trade zones among OBOR countries (Lee and Hyun, 2015).

Implementation of the OBOR requires several complementary policies involving financial infrastructure and free trade agreements. In order to support investment financing for the New Silk Road, the Chinese government has established three financial organizations. These organizations are the Asia Infrastructure Investment Bank (AIIB), the BRICS Development Bank led by Brazil, Russia, India, and South Africa, and the Silk Road Fund jointly funded by Chinese state-owned banks. To effectively promote trade, the Chinese government has a long-term plan to establish OBOR FTAs involving OBOR member nations.

As the Chinese economy is increasing its influential powers in the global economy, especially the global production network, the OBOR initiatives have raised concerns regarding the real objectives of the Chinese government, the economic implications, and the academic capabilities to properly predict the dynamic features of the interconnections among countries influenced by the New Silk Road. Even though the OBOR could have significant effects on the world economy, scholarly works on this topic are limited. One reason could be that the policy is still in the initial stages, so not enough data has been accumulated for analytical study.

Cheng (2016) discussed the real aims of the OBOR drawn from western scholars and argued that the success of the OBOR crucially depends on mutually beneficial economic cooperation. Huang (2016) argued that the OBOR's main purpose is to reshape the world trade network and to maintain sustainable growth in order to overcome decreasing economic growth in China. As for the implications of the OBOR, Sheu and Kundu (2017) proposed the effective logistics network and as for the oil freight, the Gwadar and Myanmar routes complement each other in transporting oil to China. Concerning the dynamic features of the interconnections resulting from the OBOR, based on the bilateral trade among more than 70 countries that are potential OBOR participants, and using social network analysis, Lee et al. (2015) argued that only China and Germany can reinforce its network position, and that Central Asian countries show no potential as hub positions.

This special issue of Journal of International Logistics and Trade (JILT) included selected papers which were presented at the international conferences below and submitted to the JILT journal website: "One Belt and One Road (OBOR) international conference on the Silk Road Economic Belt and the 21st Century Maritime Silk Road for Transportation and Global Supply Chain.” organized by the School of Business IT and Logistics, RMIT University, Australia". The following excerpts are a brief introduction of the two accepted papers for this special issue.

The first paper, "Supply chain security initiative: The authorized economic operator and Indonesia's experience," written by Dicky Hadi Pratama and Sophia Everett, examines the Authorized Economic Operators (AEO) program. Based on the lessons from Indonesian experiences, AEOs among the OBOR countries are required to assess challenges including legal frameworks, the enhancement of customs administrations functions, and SME issues

The second paper, "Assessing the displacement effect of exports with gravity trade model: China's textile and clothing case and OBOR implications," written by Yui-yip Lau, Man Hin Chan and Hong-Oanh Nguyen examines the displacement effects of the growth of China's textile and clothing industry on the exports of other developing Asian 
countries. The paper shows that the emergence of China's textile and clothing industry has had significant replacement effects on the growth of other Asian countries, and the replacement effects were found more prominent in the low-income countries than in the high-income countries. The authors argue that the effects of the OBOR initiative on Asian countries depend on factors such as distance, exchange rate, and labor costs.

\section{References}

Sheu, J.B,, Kundu, T., 2017. Forecasting time-varying logistics distribution flows on the One Belt-One Road strategic context. Transportation Research Part E: Logistics and Transportation Review, http://doi.org/10.1016/j.tre.2017.03.003.

Cheng, L.K., 2016. Three questions on China's Belt and Road Initiative. China Economic Review 40, 309-313.

Huang, Y., 2016. Understanding China's Belt \& Road Initiative: Motivation, framework and assessment. China Economic Review $40,314-321$

Lee, J., Hyun, K., Jin, L., 2015. China's New Silk Road: Policies and implications. Journal of International Logistics and Trade 13, $55-70$.

Jun Yeop Lee

Department of International Trade and Regional Studies, Inha University, Incheon, Korea

E-mail: jylee@inha.ac.kr

\section{Hwa-Joong Kim}

Asia Pacific School of Logistics, Inha University, Incheon, Korea

E-mail: hwa-joong.kim@inha.ac.kr 